\title{
COMMON GREENHOUSE CONDITIONING PLANTS COMPARED WITH VERSATILE GEOTHERMAL SYSTEM IN AMES, IOWA
}

\author{
Alexandros Sotirios Anifantis ${ }^{1}$, Edmund Lorencowicz ${ }^{2}$, Artur Przywara ${ }^{2}$, \\ Simone Pascuzzi ${ }^{1}$, Giuseppe Ruggiero ${ }^{1}$, Francesco Santoro ${ }^{1}$ \\ ${ }^{1}$ Department of Agricultural and Environmental Science, University of Bari Aldo Moro, Bari, Italy. \\ ${ }^{2}$ Department of Machinery Exploitation and Management of Production Processes, University of Life \\ Sciences in Lublin, Lublin, Poland. \\ alexandrossotirios.anifantis@uniba.it, edmund.lorencowicz@up.lublin.pl, \\ artur.przywara@up.lublin.pl,simone.pascuzzi@uniba.it, giuseppe.ruggiero@uniba.it, \\ francesco.santoro@uniba.it
}

\begin{abstract}
Energy consumption is one of the most important factors related to profitability in greenhouse systems, and it is a factor in both financial considerations and environmental impacts. Competitiveness in the greenhouse industry is highly dependent upon the energy demand of heating systems. This paper focuses on the use of geothermal energy in agricultural sector. A ground source heat pump system was designed for a new greenhouse complex in Ames, Iowa. An accurate study of the external air temperatures, solar radiation, time, wind speed, and boundary conditions was conducted. Electrical and heating energy, and power demands were analysed. For the greenhouse design presented, the greatest power demand was $350 \mathrm{~kW}$ for heating and $620 \mathrm{~kW}$ for cooling. These values permitted the greenhouse to be maintained at the temperature of $16.7^{\circ} \mathrm{C}$, when the external temperature ranged from $-20^{\circ} \mathrm{C}$ to $30^{\circ} \mathrm{C}$. An economic analysis was conducted considering only the energy demand cost, and this cost was compared with the equivalent energy cost of fuel oil and natural gas systems for heating and the equivalent energy cost of the fan and pad systems for cooling. For heating purposes, the economic analysis showed that the total energy demand cost over the nine years of using a closed-loop GWHP was around 120,000 USD, whereas the fuel oil system was 364,000 USD, and the natural gas system was 253,000 USD. This yields cost savings of $67 \%$ and $53 \%$, respectively. For the cooling purposes, the economic analysis is inconsistent, and the fact, the energy cost difference between the closed-loop ground source heat pump cooling system and fad and pad systems is huge, 83,000 USD for closed-loop ground source heat pump cooling and around 5,200 USD for the fan and pad system energy in nine years.
\end{abstract}

Keywords: greenhouse heating; greenhouse cooling; geothermal systems

\section{Introduction}

In food crop and ornamental greenhouses, a large amount of materials [1;2] and energy is required for climate control in order to assure good yield and a high-quality crop. Energy consumption is one of the most important factors related to profitability in greenhouse systems, and it is a factor in both financial considerations and environmental impacts [3-5]. This requirement usually is satisfied by fossil fuels, such as coal, oil, or natural gas, all of which weigh upon global warming. In addition, the price of fossil fuels has continued to rise, and it is no longer as advantageous as it was years ago. Today, older heating systems based on fossil fuels are not more sustainable for greenhouses on both environmental and economic basis. In the foreseeable future, energy sources and rates of consumption will change. Renewable energy technologies for the greenhouse industry are not ready yet to replace fossil-fuel use totally, but the interest of the public and scientific opinion grows more favourable from year to year. Several research projects are being conducted on renewable energy systems for greenhouses, heat pumps, and co-generation systems [6;7], on photovoltaic and thermal collectors for climate and ventilation supply [8-10], geothermal heating of water from artesian wells or geothermal sources [11-13] and hydrogen and renewable energy sources integrated systems for greenhouse heating [14-17]. In this paper, we will concentrate on the use of geothermal energy. Often, geothermal energy, like wind energy, is considered as a particular application for a specific place, like a hot natural-water source or an artesian well. But today, it is possible to obtain good energy efficiency from soil thermal capacity, and the only particular natural sources necessary are a good soil temperature and a relatively shallow aquifer.

\section{Materials and methods}

After an accurate evaluation, in which we have determined the advantages and disadvantages, the energy-producing capacity, environmental impact, economical aspects, installation, and the maintenance, we have chosen a closed-loop groundwater heat pump (GWHP) as the most suitable 
choice. This choice evolved from the shallow aquifer in Ames, Iowa, measured around 45m (150ft), with a water temperature of 12 to $13{ }^{\circ} \mathrm{C}\left(55.5^{\circ} \mathrm{F}\right)$. Our first choice was an open-loop system, which has greater efficiency than a closed-loop system, but it was not permitted, due to state regulations in Iowa. The main benefit of a heat pump and its associated system is the coefficient of performance (COP). Due to a high coefficient of performance, a heat pump can transform $1 \mathrm{kWh}$ of electric energy in to 4 , 5 , or $6 \mathrm{kWh}$ of heating energy, depending on the soil temperature and the ambient temperature demand. Other important factors are the heat pump characteristics, real thermodynamic cycle, and the heat pump system design and installation. Moreover, the same heat pump is functional during both cold and hot periods. This system can produce warm water for cold periods or cold water for hot periods, and this shift can be accomplished by simple inversion of the heat pump cycle. Similar to the COP for heating, there is the energy efficiency ratio (EER) for cooling. The main disadvantages of GWHP are the initial high cost and the slow speed of traversing official channels in order to obtain the authorization to drill boreholes through the aquifer for heating purposes.

A GWHP system was designed for a new Department of Horticulture greenhouse complex at the Iowa State University in Ames, Iowa. The greenhouse complex will be composed of eight research compartments and six instructional compartments. Each compartment is of a size to allow operation of a small self-propelled root-harvesting machine [18]. Between the research and instructional ranges, an open-roof greenhouse range will be built for overwintering woody ornamentals. The total area is $1,160 \mathrm{~m}^{2}\left(12,500 \mathrm{ft}^{2}\right)$, and the heated area, less than the open-roof greenhouse, is around $840 \mathrm{~m}^{2}$ $\left(9,040 \mathrm{ft}^{2}\right)$. Each greenhouse compartment will be furnished with an in-floor, pipe-coil heating system composed of $19 \mathrm{~mm}(3 / 4 ")$ cross-linked polyethylene (PEX) to assure a lower cost and freedom from breakage. Warm water will be circulated through the in-floor pipe system in order to maintain a minimum temperature of $16.7^{\circ} \mathrm{C}\left(62^{\circ} \mathrm{F}\right)$ inside the greenhouse, with the water circulating through the system of temperatures from $30^{\circ} \mathrm{C}$ to $60^{\circ} \mathrm{C}\left(86^{\circ} \mathrm{F}\right.$ to $\left.140{ }^{\circ} \mathrm{F}\right)$ [19]. The GWHP supplies the in-floor pipe heating system, and it is composed of three hydraulic circuits. The first circuit is a closed-loop system with 63 geothermal boreholes through the aquifer, and each borehole is $140 \mathrm{~m}$ (460ft) deep with a specific extraction rate of $52 \mathrm{~W} \cdot \mathrm{m}^{-1}$. During winter, heat is extracted from the soil to produce hot water to heat the greenhouse, and during summer, the heat transfer process can be reversed (with a reversible heat pump) in order to produce cold water and cool air to reduce the temperature of the growing space. The second circuit is connected to the heat pump, and it is a closed-loop composed of two heat exchangers, a thermal expansion valve and compressor for making the thermodynamic cycle. The third circuit is also a closed-loop system, and it consists of the in-floor pipe heating system. During the last years in Ames, the ambient air-temperature range was $-36{ }^{\circ} \mathrm{C}\left(-33^{\circ} \mathrm{F}\right)$ to $36{ }^{\circ} \mathrm{C}\left(97^{\circ} \mathrm{F}\right)$ over the entire set of years, but for the most part, the temperature ranged from $-20^{\circ} \mathrm{C}\left(-4^{\circ} \mathrm{F}\right)$ to $30^{\circ} \mathrm{C}$ $\left(86^{\circ} \mathrm{F}\right)[20 ; 21]$.

\section{Results and discussion}

In accordance with Table 1 and Table 2, the greatest heat power demand was determined to be $460 \mathrm{~kW}\left(1,570 \mathrm{MBtu} \cdot \mathrm{h}^{-1}\right)$.

Table 1

Energy and economic analysis for a closed-loop ground water heat pump system and a fan and pad cooling systems with external air temperatures up to $16.7^{\circ} \mathrm{C}$

\begin{tabular}{|c|c|c|c|c|c|c|c|c|c|c|c|}
\hline $\begin{array}{c}\text { Power } \\
\text { demand } \\
\text { range }\end{array}$ & $\begin{array}{c}\text { Power } \\
\text { ave. }\end{array}$ & Time & $\begin{array}{c}\text { Cooling } \\
\text { Energy } \\
\text { demand }\end{array}$ & $\mathbf{C O P}$ & $\begin{array}{c}\text { Electric } \\
\text { Energy } \\
\text { consumed }\end{array}$ & $\mathbf{F a n}$ & $\begin{array}{c}\text { Power } \\
\text { of } \\
\text { each } \\
\text { fan }\end{array}$ & $\begin{array}{c}\text { Fan } \\
\text { total } \\
\text { power }\end{array}$ & $\begin{array}{c}\text { FAN } \\
\text { Electric } \\
\text { Energy }\end{array}$ & GWHP & $\begin{array}{c}\text { FAN } \\
\mathbf{\&} \\
\text { PAD }\end{array}$ \\
\hline $\mathbf{k W}$ & $\mathbf{k W}$ & $\mathbf{h}$ & $\mathbf{k W h}$ & & $\mathbf{k W h}$ & $\mathbf{n}^{\mathbf{0}}$ & $\mathbf{W}$ & $\mathbf{k W}$ & $\mathbf{k W h}$ & $\mathbf{U S D}$ & USD \\
\hline $0-20$ & 10 & 2467 & 24670 & - & 247 & 1 & 15 & 0.02 & 38 & 19 & 4 \\
\hline $100-120$ & 110 & 839 & 92290 & 8 & 11201 & 4 & 259 & 1.03 & 868 & 862 & 87 \\
\hline $200-220$ & 210 & 614 & 128940 & 7 & 18465 & 5 & 339 & 1.69 & 1039 & 1422 & 104 \\
\hline $300-320$ & 310 & 557 & 172670 & 7 & 25888 & 7 & 387 & 2.71 & 1507 & 1993 & 151 \\
\hline $400-420$ & 410 & 635 & 260350 & 5 & 50075 & 8 & 495 & 3.96 & 2517 & 3856 & 252 \\
\hline $500-520$ & 510 & 626 & 319260 & 4 & 77192 & 9 & 494 & 4.45 & 2783 & 5944 & 279 \\
\hline $600-620$ & 610 & 224 & 136640 & 3 & 50817 & 9 & 572 & 5.15 & 1153 & 3913 & 115 \\
\hline $660-680$ & 670 & 18 & 12060 & - & - & 9 & 522 & 4.70 & 85 & - & 8 \\
\hline Total & - & - & 5854190 & & 1073401 & - & - & - & 51654 & 82652 & 5171 \\
\hline
\end{tabular}


Table 2

Air and water parameters for a closed-loop ground water heat pump system and fan and pad cooling systems with external air temperatures up to $16.7^{\circ} \mathrm{C}$

\begin{tabular}{|c|c|c|c|c|c|c|c|c|c|c|c|c|}
\hline $\begin{array}{c}\text { Power } \\
\text { demand } \\
\text { range }\end{array}$ & $\begin{array}{c}\text { T } \\
\text { ext_air } \\
\text { max }\end{array}$ & $\begin{array}{c}\text { T } \\
\text { ext_air } \\
\text { min }\end{array}$ & $\begin{array}{c}\text { T } \\
\text { ext_air } \\
\text { ave. }\end{array}$ & $\begin{array}{c}\text { T } \\
\text { water } \\
\text { pipe }\end{array}$ & $\begin{array}{c}\text { RH } \\
\text { ext_air } \\
\text { max }\end{array}$ & $\begin{array}{c}\text { RH } \\
\text { ext_air } \\
\text { min }\end{array}$ & $\begin{array}{l}\text { RH } \\
\text { ext_air } \\
\text { ave. }\end{array}$ & $\begin{array}{c}T \\
\text { int_air } \\
\text { with } \\
\text { PAD } \\
\text { eff. } \\
85 \% \\
\end{array}$ & 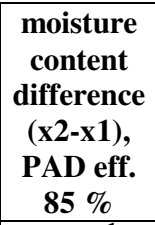 & $\begin{array}{c}\text { Air } \\
\text { Flow } \\
\text { Rate } \\
\text { FAN }\end{array}$ & $\begin{array}{l}\text { H2O } \\
\text { evap. }\end{array}$ & $\begin{array}{l}\mathrm{H} 2 \mathrm{O} \\
\text { circ. }\end{array}$ \\
\hline kW & ${ }^{\circ} \mathrm{C}$ & ${ }^{\circ} \mathrm{C}$ & ${ }^{\circ} \mathrm{C}$ & ${ }^{\circ} \mathrm{C}$ & $\%$ & $\%$ & $\%$ & ${ }^{\circ} \mathrm{C}$ & $\mathrm{g} \cdot \mathrm{kg}^{-1}$ & $\mathrm{~m}^{3} \cdot \mathbf{h}^{-1}$ & $\mathbf{l} \cdot \mathbf{h}^{-1}$ & $\mathbf{l} \cdot \mathbf{h}^{-1}$ \\
\hline $0-20$ & 18.5 & 16.7 & 17.6 & 15.2 & 100 & 18 & 84 & 16.2 & 0.6 & 21777 & 16 & 159 \\
\hline $100-120$ & 27.8 & 16.7 & 22.8 & 6.9 & 100 & 13 & 76 & 20.3 & 1.0 & 140913 & 175 & 1746 \\
\hline $200-220$ & 32.4 & 16.7 & 23.4 & 6.0 & 100 & 1 & 65 & 19.5 & 1.5 & 178842 & 333 & 3333 \\
\hline $300-320$ & 33.8 & 16.7 & 23.6 & 5.7 & 100 & 1 & 62 & 19.3 & 1.7 & 233946 & 492 & 4921 \\
\hline $320-340$ & 34.0 & 16.7 & 23.6 & 5.6 & 100 & 16 & 61 & 19.2 & 1.7 & 247812 & 524 & 5238 \\
\hline $400-420$ & 34.6 & 16.7 & 24.6 & 4.0 & 100 & 13 & 58 & 19.7 & 1.9 & 277783 & 651 & 6508 \\
\hline $500-520$ & 35.9 & 16.9 & 25.9 & 2.0 & 100 & 7 & 54 & 20.3 & 2.2 & 300175 & 810 & 8095 \\
\hline $600-620$ & 35.0 & 23.1 & 29.1 & -3.1 & 80 & 2 & 52 & 22.8 & 2.5 & 315219 & 968 & 9683 \\
\hline $660-680$ & 34.0 & 26.0 & 31.3 & -6.6 & 74 & 34 & 49 & 24.2 & 2.8 & 305797 & 1063 & 10635 \\
\hline
\end{tabular}

However, this extreme occurred infrequently, and we believe the best value for the heat-pump power is $350 \mathrm{~kW}\left(1,194 \mathrm{MBtu} \cdot \mathrm{h}^{-1}\right)$. The greatest cold-power demand was determined to be $680 \mathrm{~kW}$ $\left(2,320 \mathrm{MBtu} \cdot \mathrm{h}^{-1}\right)$, but again, the best value, considering the power time frequency, is $620 \mathrm{~kW}$ $\left(2,116 \mathrm{MBtu} \cdot \mathrm{h}^{-1}\right)$.

This is confirmed also by observing the demand for the energy in Fig. 2 and Fig. 3, in fact the energy necessary for heat power demands greater than $350 \mathrm{~kW}\left(1,194 \mathrm{MBtu} \cdot \mathrm{h}^{-1}\right)$ is less than $387,000 \mathrm{kWh}(1,320 \mathrm{MMBtu})$ per nine years, that is less than $6 \%$ of the total energy demand. It is possible to do similar calculations for cooling. In this case, the energy necessary for cooling power request greater than $620 \mathrm{~kW}\left(2,116 \mathrm{MBtu} \cdot \mathrm{h}^{-1}\right)$ is less than $2 \%$ of the total energy demand. Thus, a power demand of $620 \mathrm{~kW}\left(2,116 \mathrm{MBtu} \cdot \mathrm{h}^{-1}\right)$ adequately meets the needs of the system, because the yearly energy and power demand is not needed continuously.
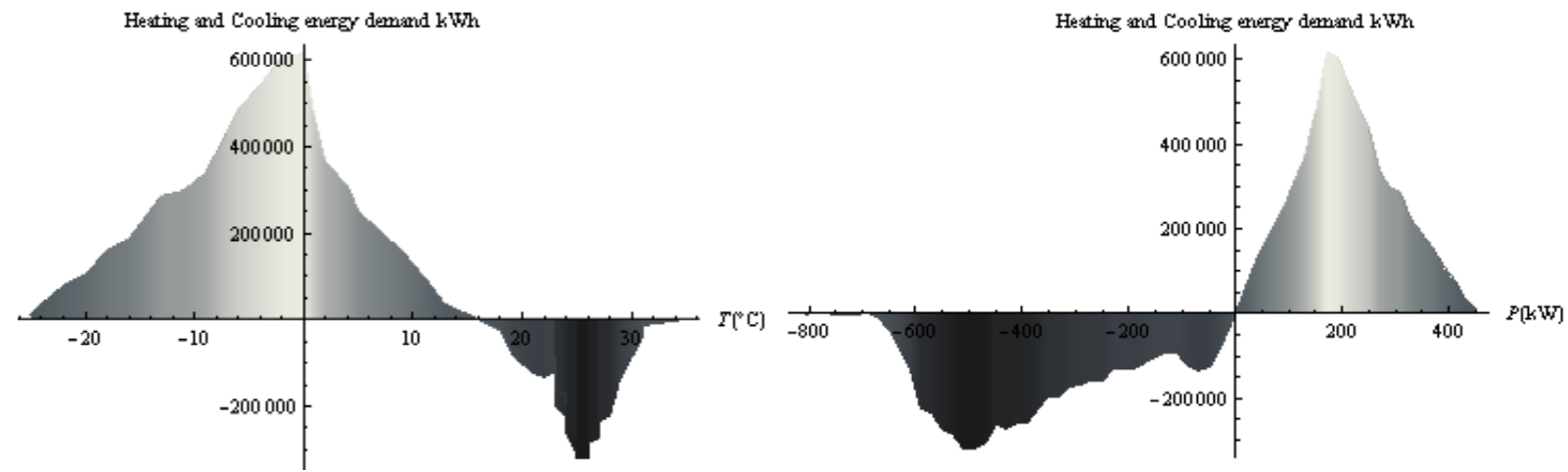

Fig. 2. Heating and cooling energy demand and Fig. 3. Heating and cooling energy demand and average external air temperature average power demand

We have completed an accurate study of the external air temperatures, solar radiation, time, wind speed, and boundary conditions for Ames, Iowa, during the last nine years. For the greenhouse design presented, we found that the greatest power demand was $350 \mathrm{~kW}$ for heating and $620 \mathrm{~kW}$ for cooling. These values permitted the greenhouse to be maintained at the temperature of $16.7^{\circ} \mathrm{C}\left(62^{\circ} \mathrm{F}\right)$, when the external temperature ranged from $-20^{\circ} \mathrm{C}\left(-4^{\circ} \mathrm{F}\right)$ to $30^{\circ} \mathrm{C}\left(86^{\circ} \mathrm{F}\right)$. The heating time is $55 \%$ of the total time period of nine years, whereas the cooling time is $34 \%$, and natural ventilation time is the $11 \%$. Instead, the percent value changed a little for what concerns energy; in fact, almost one-half of the total energy demand is required for heating $(47 \%)$ and the other half for cooling $(44 \%)$. Unfortunately, the cooling energy supplied by natural ventilation represented only $9 \%$ of the total energy demand. Some interesting considerations are exhibited in Fig. 3. The greatest heating energy demand corresponds to a power demand of around $160 \mathrm{~kW}$, and the energy distribution in Fig. 2 is 
similar to the Gaussian bend, instead for cooling the peak of energy demand corresponded to a power around $500 \mathrm{~kW}$, higher than the heating power and not following normal distribution, maybe for the combined effects of the sun and the greater external temperatures. Also an external air temperature around $0{ }^{\circ} \mathrm{C}$ corresponds to the greatest heating energy demand, and at $25^{\circ} \mathrm{C}$ it corresponded to the greatest cooling energy demand. The design of the entire system should be completed by using these power demands and the temperature values so that we obtain the greatest efficiency. The electric power consumption, to satisfy the heating and cooling energy demand, changes as the coefficient of performance or the energy efficiency ratio changes in accordance with the external conditions. In our model system for heating, the COP decreases as the external air temperature decreases, and the heating power demand increases. In particular, the COP is seven, when the hot water temperature circulated through the secondary circuit of the heat pump is $30^{\circ} \mathrm{C}\left(86^{\circ} \mathrm{F}\right)$, and it is 3 , when the temperature is $60^{\circ} \mathrm{C}\left(140^{\circ} \mathrm{F}\right)$. Consequently, the greatest value of the COP weighted average of the closed-loop GWHP is equal to 4.7, when the weighted value is equivalent to the amount of hours of each COP value. In the case of the cooling system, the EER is 6.7, larger than the COP, because the temperature of the soil and the aquifer is around $13{ }^{\circ} \mathrm{C}$, which is lower than the greenhouse temperature required. Due to the greater COP and EER, it is possible to transform 2,480,000 kWh of electrical energy into $11,713,000 \mathrm{kWh}$ of heating and cooling energy necessary for the nine years of greenhouse climate conditioning (Table 1), and then it is possible to obtain total energy savings of around $78 \%$.

For heating purposes, our economic analysis shows that the total energy demand cost over the nine years of using a closed-loop GWHP is around 120,000 USD, whereas the fuel oil system is 364,000 USD, and the natural gas system is 253,000 USD. This yields cost savings of $67 \%$ and $53 \%$, respectively. It must be considered that the cost of energy increases from year to year and even if the percentages of the price differences between electric energy and fuel oil or electric energy and gas are considered constant, the price differences increase. For the cooling purposes, the economic analysis is inconsistent, and the fact, the energy cost difference between the closed-loop GWHP cooling system and fad and pad systems is huge, as shown in Table 2, 83,000 USD for closed-loop GWHP cooling and around 5,200 USD for the fan and pad system energy in nine years. But, the substantial difference between the two systems is that with the fan and pad system it is impossible to set and maintain uniform temperature and humidity [22], it is also an important requisite to limit the contamination issues on the workers operators [23-26].

\section{Conclusions}

For a complete economic analysis, we must consider the total cost of the energy demand including all equipment, drilling work, etc., and this analysis should be done in the future. We considered only the energy demand cost, and this cost was compared with the equivalent energy cost of fuel oil and natural gas systems for heating and the equivalent energy cost of the fan and pad systems for cooling. However, both from an energy and economic point of view, the use of geothermal energy for greenhouse heating and cooling is sustainable. Considering the analysis carried out, a power plant of $620 \mathrm{~kW}$ adequately meets the needs of the system, because the yearly energy and power demand is not needed continuously. For the greenhouse design presented, it was found that the greatest power demand was for the heating purpose and less for cooling.

Unfortunately, the cooling energy supplied by natural ventilation represented only a small percent of the total energy demand. For heating purposes, our economic analysis shows that the total energy demand cost over the nine years of using a closed-loop GWHP is very advantageous in respect to the fuel oil systems and the natural gas systems. This yields cost savings of $67 \%$ and $53 \%$, respectively. For the cooling purposes, the economic analysis is inconsistent, and the fact, the energy cost difference between the closed-loop GWHP cooling system and the fad and pad systems is huge.

\section{References}

[1] Anifantis A., Canzio G., Cristiano G., De Lucia B., Russo G., Vecchietti L., Immirzi B., Malinconico M., Santagata G. Influence of the use of drip irrigation systems and different mulching materials on ornamental sunflowers in greenhouse cultivation. Acta Hortic., vol. 952, 2012, pp. 385-392. 
[2] Russo G., Verdiani G., Anifantis A. S. Re-use of agricultural biomass for nurseries using proximity composting. Contemporary Engineering Sciences, vol. 9(24), 2016, pp. 1151-82.

[3] Korner O., Bakker M.J., Heuvelink E., Daily temperature integration: A simulation study to quantify energy consumption. Biosystem Engineering., vol 87, 2004, pp. 67-77.

[4] Anifantis A.S., Colantoni A., Pascuzzi S., Santoro F. Photovoltaic and hydrogen plant integrated with a gas heat pump for greenhouse heating: A mathematical study. Sustainability, vol.10(2), 2018, pp.378-389.

[5] Anifantis A. S., Pascuzzi S., Santoro F. Performance comparison between fuel cell coupled with geothermal source heat pump and geothermal source gas engine heat pump system for greenhouse heating: a mathematical study. Engineering for Rural Development, 2018, pp. 1692-1697.

[6] García J.L., De la Plaza S, Navas. L.M., Benavente R.M., Luna L. Evaluation of the feasibility of alternative energy sources for greenhouse heating. Journal of Agricultural Engineering Research, vol. 69, 1998, pp. 107-114.

[7] Anifantis A. S., Colantoni A., Pascuzzi S. Thermal energy assessment of a small scale photovoltaic, hydrogen and geothermal stand-alone system for greenhouse heating. Renewable Energy, 2017, vol. 103, pp. 115-27.

[8] Rocamora M.C., Tripanagnostopoulos Y. Aspects of PV/T solar system application for ventilation needs in greenhouses. Acta Horticultural., vol. 719, 2006, pp. 239-245.

[9] Anifantis A. S., Przywara A., Pascuzzi S., Santoro F. Performance of photovoltaic and ground source heat pump system for daytime cooling of mushroom greenhouse during summer: preliminary analysis. Engineering for Rural Development, 2018, pp. 1684-1691.

[10] Anifantis A.S. Performance assessment of photovoltaic, ground source heat pump and hydrogen heat generator in a stand-alone syst. for greenhouse heating. Chemical Engineering Transaction, vol. 58, 2017, pp. 511-516.

[11] Nikita-Martzopoulou C. Greenhouse heating systems with geothermal energy of low enthalpy in Greece. Acta Horticultural, vol. 263, 1990, pp. 183-190.

[12] Karytsas C., Mendrinos D., Goldbrunner J. Low enthalpy geothermal energy utilisation schemes for greenhouse and district heating at Traianoupolis Evros, Greece. Geothermics, vol.32, 2003, pp.69-78.

[13] Anifantis A. S., Pascuzzi S., Scarascia Mugnozza G. Geothermal source heat pump performance for a greenhouse heating system: An experimental study. Journal of Agricultural Engineering, vol. 47(3), 2016, pp.164-70.

[14]Pascuzzi S., Anifantis A. S., Blanco I., Scarascia Mugnozza G. Electrolyzer performance analysis of an integrated hydrogen power system for greenhouse heating a case study. Sustainability (Switzerland), vol. 8(7), 629, 2016, pp. 1-15.

[15] Pascuzzi S., Blanco I., Anifantis A. S., Scarascia Mugnozza G. Hazards assessment and technical actions due to the production of pressured hydrogen within a pilot photovoltaic-electrolyzer-fuel cell power system for agricultural equipment. Journal of Agricultural Engineering, vol. XLVII:507 No 2, 2016, pp. 88-93.

[16] Blanco I., Pascuzzi S., Anifantis A. S., Scarascia Mugnozza G. Study of a pilot photovoltaicelectrolyzer-fuel cell power system for a geothermal heat pump heated greenhouse and evaluation of the electrolyzer efficiency and operational mode. Journal of Agricultural Engineering, vol. XLV:238 No 3, 2014, pp. 111-118.

[17]Blanco I, Anifantis A. S., Pascuzzi S, Scarascia Mugnozza G. Hydrogen and renewable energy sources integrated system for greenhouse heating. Journal of Agricultural Engineering, vol. XLIV S2, 2013, pp. 226-230.

[18] Bulgakov V., Pascuzzi S., Santoro F., Anifantis A. S. Mathematical Model of the Plane-Parallel Movement of the Self-Propelled Root-Harvesting Machine. Sustainability, vol. 10(10), 2018, No 3614.

[19] Nelson P. V. Greenhouse Operation \& Management. Sixth ed. Upper Saddle River, New Jersey. Prentice Hall. 2003.

[20] IEM Networks. Iowa Environmental Mesonet, Iowa State University Department of Agronomy. Hourly Data. http://mesonet.agron.iastate.edu/agclimate/index.phtml

[21] USGS Water Resources. Water Quality Samples for USA: Sample Data. [online][15.04.2019] Available at: http://nwis.waterdata.usgs.gov/usa/nwis/qwdata? 
[22] Bucklin R.A., Leary J.D., McConnell D.B., Wilkerson E.G. Fan and Pad Greenhouse Evaporative Cooling Systems. University of Florida (IFAS) CIR1135. March 2016.

[23] Cerruto E., Manetto G., Santoro F., Pascuzzi S. Operator Dermal Exposure to Pesticides in Tomato and Strawberry Greenhouses from Hand-Held Sprayers. Sustainability, vol. 10(7), 2018, No 2273. DOI: $10.3390 /$ su10072273

[24] Manetto G., Cerruto E., Pascuzzi S., Santoro F. Improvements in citrus packing lines to reduce the mechanical damage to fruit. Chem. Eng. Trans. 58, 2017, pp. 391-396. http://dx.doi.org/10.3303/CET1758066

[25] Pascuzzi S., Cerruto E., Manetto G. Foliar spray deposition in a "tendone" vineyard as affected by airflow rate, volume rate and vegetative development. Crop Protection 2017, 91, pp. 34-48. 10.1016/j.cropro.2016.09.009

[26] Pascuzzi S., Santoro F. Exposure of farm workers to electromagnetic radiation from cellular network radio base stations situated on rural agricultural land. International Journal of Occupational Safety and Ergonomics 2015, 21 (3), pp. 351-358. 